\title{
PEMODELAN MATEMATIKA MANFAAT JUMLAH RAKAAT SHALAT PADA PEMBAKARAN KALORI DALAM TUBUH
}

\author{
Indah Nursuprianah \\ indahnursuprianah@gmail.com \\ IAIN Syekh Nurjati Cirebon
}

\begin{abstract}
ABSTRAK
Shalat adalah ibadah yang agung, ibadah yang dibuka dengan takbir dan ditutup dengan salam. Shalat juga ibadah yang terpenting setelah kedua kalimat syahadat. Perintah sholat itu juga tertuang dalam Al- Qur'an Surat Al Ankabut : 45. Selain kewajiban tentang shalat di atas ternyata shalat yang tumakninah juga bermanfaat untuk kesehatan. Pembakaran kalori dalam setiap jumlah rakaat shalat, mampu membuat tubuh menjadi sehat. Satu rakaat shalat ternyata mampu membakar sekitar 25 kalori. Sehingga semakin banyak jumlah rakaat shalat dapat memperbanyak pembakaran kalori dalam tubuh. Total banyaknya kalori yang terbakar pada saat melakukan shalat yang tumakninah dalam satu hari adalah 525 kalori dengan diasumsikan 5 waktu shalat wajib 17 rakaat dan 2 waktu shalat sunah 4 rakaat tanpa menghitung shalat sunah Rawatib. Dari beberapa penelitian, banyak sekali manfaat dari shalat untuk kesehatan fisik maupun psikis. Dalam penelitian ini penulis mencoba untuk mengkaji manfaat gerakan rakaat shalat yang tumakninah pada pembakaran kalori dalam tubuh. Selain itu penelitian ini juga akan ditunjukkan bagaimana membuat model matematika manfaat jumlah rakaat shalat pada pembakaran kalori dalam tubuh yang selanjutnya akan berefek pada kesehatan.
\end{abstract}

Kata kunci: Pemodelan Matematika, jumlah rakaat shalat, pembakaran kalori dalam tubuh

\begin{abstract}
Salah is a grand Muslim worship that starts with takbir and ends by salam. Salat is also the most important worship after syahadah. The command of salat is stated in Noble Quran, Al Ankabut chapter (Surah): verse of 45. In addition to the following command of salah, in fact the peaceful (tumakninah) salah benefits healthy. Calorie burning in every rakaat (the repetition of a unit in salah) of salah, is able to build healthy body. One rakaat is able to burn around 25 calories. So that, the more rakaat in salah, the more calories burnt in our bodies. Total of burnt calories during salah with tukmaninah in a day is 525 calorie with the following assumptions: 5 times of obligatory (fardhu) salah, 17 rakaats and 2 sunnah (optional) salah 4 rakaats without sunnah rawatib salah. Based on some researches, there are a lot of advantages of salah for physical and mental health. Through this research, the writer has attempted to review the advantage of motion of tukmaninah salah over calorie burning in bodies. The research also indiacates how to create mathematical modelling of the advantage of total rakaat of salah over calorie burning in bodies that eventually affect to health.
\end{abstract}

Key words: Mathematical modelling, number of rakaah, calorie burning in body

\section{PENDAHULUAN}

Shalat adalah ibadah yang agung, ibadah yang dibuka dengan takbir dan ditutup dengan salam, dan ibadah yang terpenting setelah kedua kalimat syahadat. Dari Ibnu Umar radhiallahu anhuma dia berkata: Rasulullah shallallahu 'alaihi wasallam bersabda:

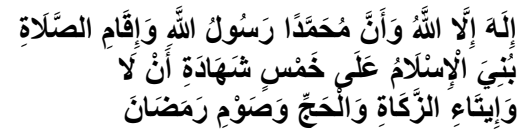

"Islam dibangun diatas lima (landasan); persaksian tidak ada ilah selain Allah dan sesungguhnya Muhammad utusan Allah, mendirikan shalat, menunaikan 
zakat, haji dan puasa Ramadhan”. (HR. Al-Bukhari no. 7 dan Muslim no. 19)

Perintah sholat itu juga tertuang dalam Al- Qur'an Surat Al Ankabut : 45 yang artinya :

"Bacalah apa yang telah diwahyukan kepadamu dari alkitab dan dirikanlah shalat, sesungguhnya shalat itu mencegah manusia dari perbuatan keji dan munkar, dan sungguh ingat pada Allah itu lebih besar (manfaatnya) dan allah mengetahui apa yang kamu kerjakan “.

Sholat di ibaratkan sebuah tiang dalam bangunan, berguna sebagai penyangga ataupun sebagai tempat di tempelkannya sesuatu. Bayangkanlah jika sebuah bangunan tanpa tiang, tentunya tak akan dapat berdiri kokoh apalagi dipasangi dinding. Maka barang siapa yang mengingkari amal perbuatan Shalat, meski mengakui dirinya sebagai seorang muslim sama saja dengan orang munafik, karena pernyataan lisannya tidak sesuai dengan hati dan amal perbuatan, karena kesempurnaan iman terletak pada keselarasan antara hati, perkataan dan perbuatan. Sebagaimana definisi iman itu sendiri : " Iman itu adalah sesuatu yang di yakini di dalam hati, di ikrarkan dengan lisan serta diamalkan dengan perbuatan ".

Tidak ada istilah berislam itu cukup hanya dengan mengerjakan amalan - amalan sholeh serta menanamkan kebaikan terhadap sesama, tidak perlu melaksanakan sholat. Biasanya yang berpendapat demikian adalah manusia yang salah kaprah dalam memahami makna sholat, " sesungguhnya sholat itu dapat mencegah perbuatan keji dan munkar “

Jika kita mau berpijak pada sejarah Rosullulah saw dan para sahabat, setelah perintah shalat diterima mereka tidak pernah meninggalkan kewajiban tersebut. Bahkan dalam situasi serta kondisi yang bagaimanapun beratnya, bahkan saat dalam situasi perang sekalipun shalat tetap mereka kerjakan. Maka dalam ajaran islam ada tata cara sholat Khauf (dalam keadan perang), bahkan Rosullulah saw mengajarkan pada pengikutnya tata cara sholat dalam kondisi sakit (shalat bebaring dan dengan isyarat anggota tubuh). Semua itu menandakan bahwa perintah sholat adalah menjadi kewajiban mutlak bagi pemeluk agam islam untuk di laksanakan dengan gerakan, tidak cukup sekedar niat saja atau meyakini kewajibannya tetapi mengingkari perbuatannya ( tidak mau melaksanakannya).

Shalat yang dibahas di sini terbagi menjadi 7 bagian waktu, yaitu 5 shalat wajib (subuh, zuhur, ashar, magrib, isya) dan 2 shalat sunnah (dhuha dan tahajud). Dengan jeda waktu antara 1 jam yang paling dekat yaitu shalat Magrib ke Isya, dan 5 jam yaitu dari isya ke tahajud. Dalam pembentukan model matematika ini tidak dilihat jeda waktu antar shalat satu dengan yang lain, tetapi yang dihitung adalah banyaknya rakaat salat yang tumakninah dengan pembakaran kalori dalam tubuh.

Selain kewajiban tentang shalat di atas ternyata shalat juga bermanfaat untuk kesehatan. Pembakaran kalori dalam setiap jumlah rakaat shalat, mampu membuat tubuh menjadi sehat dan segar. Satu rakaat shalat ternyata mampu membakar sekitar 25 kalori. Sehingga semakin banyak jumlah rakaat shalat dapat memperbanyak pembakaran kalori dalam tubuh.

Shalat yang berpengaruh pada kesehatan tubuh telah dibahas oleh beberapa ahli maupun dokter. Seperti pada penelitian Deden Suparman, MA Fakultas Sains dan Teknologi (2015) yang berjudul "Pembelajaran Ibadah Shalat dalam Perpektif Psikis dan Medis" dalam Jurnal UIN Sunan Gunung Djati Bandung Edisi Juli 2015 Volume IX No. 2 ISSN 1979-8911 yang melihat shalat bukan hanya sebagai bentuk ibadah tetapi manfaat untuk tubuh baik secara Psikis maupun Medis.

Selain penelitian di atas, Sabiq

M. Azam Zaenal Abidin dari Fakultas Psikologi Universitas Diponegoro Semarang (2014) yang berjudul "Efektivitas Shalat Tahajud dalam Mengurangi Tingkat Stres Santri” dalam jurnal Fakultas Psikology UII juga menyebutkan manfaat dari shalat tahajud terhadap kesehatan psikis .

Untuk penderita Diabetes Melitus, dalam penelitian Mukhamad 
Rajin, Zulfa Khusniyah, Andi Yudianto, Muhammad Zulfikar Asumta (2015) yang berjudul "Potensi Shalat Dengan Gerakan Isotonik Dan Isometrik Predominan Untuk Menurunkan Kadar Glukosa Darah Postpandrial Pasien Diadetes Mellitus" JURNAL EDU HEALTH, VOL. 5 No. 1, APRIL 2015 halaman 75-81 merupakan penelitian manfaat dari gerakan rakaat shalat pada kesehatan fisik.

Dari beberapa penelitian di atas, jelaslah bahwa banyak sekali manfaat dari shalat untuk kesehatan fisik maupun psikis. Sehingga dalam penelitian ini penulis mencoba untuk mengkaji manfaat gerakan rakaat shalat yang tumakninah pada pembakaran kalori dalam tubuh. Selain itu penelitian ini juga akan ditunjukkan bagaimana membuat model matematika manfaat jumlah rakaat shalat pada pembakaran kalori dalam tubuh yang selanjutnya akan berefek pada kesehatan.

\section{LANDASAN TEORI}

\section{Definisi Sholat}

Menurut Hasbi Ash-Shiddieqy, sholat yaitu beberapa ucapan dan perbuatan yang dimulai dengan takbir, disudahi dengan salam, yang dengannya kita beribadah kepada Allah dengan syarat - syarat yang telah ditentukan.

Shalat lima waktu mempunyai beberapa keistimewaan dibandingkan semua ibadah wajib lainnya, di antaranya:

1. Shalat 5 waktu merupakan ibadah yang Allah Ta'ala syariatkan kepada Nabi-Nya shallallahu alaihi wasallam secara langsung tanpa perantara malaikat. Berbeda halnya dengan kewajiban lainnya yang diwajibkan melalui perantara malaikat.

2. Shalat 5 waktu diwajibkan di langit sementara kewajiban lainnya diwajibkan di bumi. Karenanya sangat pantas kalau shalat 5 waktu dikatakan sebagai ibadah badan yang paling utama.

Perintah shalat salah satunya ada di QS. Al Isra : 78 yaitu Allah Ta'ala berfirman:

$$
\text { إلى الـ شمس لددوك الد الـ صدلاة أق م }
$$

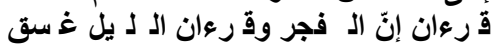

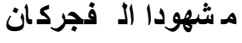

"Dirikanlah shalat dari sesudah matahari tergelincir sampai gelap malam dan (dirikanlah pula shalat) subuh. Sesungguhnya shalat subuh itu disaksikan (oleh malaikat).”(QS. Al-Isra: 78)

\section{Tuma'ninah Dalam Shalat}

Di antara kesalahan besar yang terjadi pada sebagian orang yang shalat: tidak tuma'ninah ketika shalat. Nabi shallallahu 'alaihi wa sallam menganggapnya sebagai pencuri yang paling buruk, sebagaimana disebutkan dalam Musnad Imam Ahmad dari Nabi shallallahu 'alaihi wasallam, bahwa beliau bersabda,

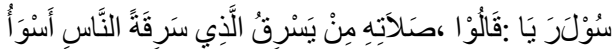

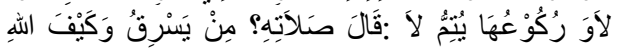

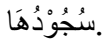

"Sejahat-jahat pencuri adalah yang mencuri dari shalatnya". Para sahabat bertanya, "Wahai Rasulullah, bagaimana mencuri dari sholat?". Rasulullah berkata, "Dia tidak sempurnakan ruku dan sujudnya" (HR Ahmad no 11532, dishahihkan oleh al Albani dalam Shahihul Jami’ 986)

Maka Nabi shallallahu
'alaihi wasallam menganggap
perbuatan mencuri dalam shalat ini
lebih buruk dan lebih parah
daripada mencuri harta.

Tuma'ninah ketika

mengerjakan shalat adalah bagian dari rukun shalat, shalat tidak sah kalau tidak tuma'ninah. Nabi shallallahu 'alaihi wa sallam pernah berkata kepada orang yang shalatnya salah,

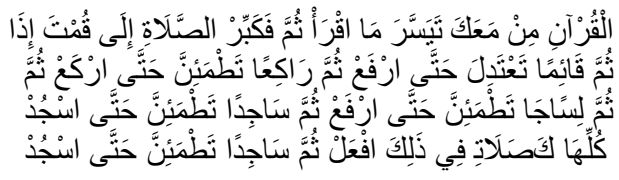

"Jika Anda hendak mengerjakan shalat maka bertakbirlah, lalu bacalah ayat al Quran yang mudah 
bagi Anda. Kemudian rukuklah sampai benar-benar rukuk dengan tumakninah, lalu bangkitlah (dari rukuk) hingga kamu berdiri tegak, setelah itu sujudlah sampai benarbenar sujud dengan tumakninah, lalu angkat (kepalamu) untuk duduk sampai benar-benar duduk dengan tumakninah, setelah itu sujudlah sampai benar-benar sujud, Kemudian lakukan seperti itu pada seluruh shalatmu" (HR Bukhari 757 dan Muslim 397 dari sahabat Abu Hurairah)

Para ulama mengambil kesimpulan dari hadits ini bahwa orang yang ruku' dan sujud namun tulangnya belum lurus, maka shalatnya tidak sah dan dia wajib mengulangnya, sebagaimana Nabi shallallahu 'alaihi wa sallam yang berkata kepada orang yang tata cara shalatnya salah ini, "Ulangi shalatmu, sejatinya Anda belumlah shalat".

Seperti halnya perintah para ulama untuk tumakninah dalam shalat, ternyata dengan melakukan tumakninah, manfaat shalat lebih besar yaitu pembakaran kalori dalam tubuh semakin efektif. Dari hal ini dapatlah disimpulkan bahwa tidaklah suatu perintah tanpa disertai manfaat.

Analisis Regresi

\section{Analisis}

regresi dalam statistika adalah salah satu metode untuk menentukan hubungan sebab-akibat antara satu variabel dengan variabel(-variabel) yang lain. Variabel "penyebab" disebut dengan bermacammacam istilah: variabel penjelas, variabel eksplanatorik, variabel independen, atau secara bebas, variabel $X$ (karena seringkali digambarkan dalam grafik sebagai absis, atau sumbu X). Variabel terkena akibat dikenal sebagai variabel yang dipengaruhi, variabel dependen, variabel terikat, atau variabel $Y$. Kedua variabel ini dapat merupakan variabel acak (random), namun variabel yang dipengaruhi harus selalu variabel acak.

Analisis regresi adalah salah satu analisis yang paling populer dan luas pemakaiannya. Analisis regresi dipakai secara luas untuk melakukan prediksi dan ramalan, dengan penggunaan yang saling melengkapi dengan bidang pembelajaran . Analisis ini juga digunakan untuk memahami variabel bebas mana saja yang berhubungan dengan variabel terikat, dan untuk mengetahui bentuk-bentuk hubungan tersebut. Dalam penelitian ini digunakan Regresi Eksponensial.

\section{METODOLOGI DAN DESIGN PENELITIAN}

Metode yang digunakan dalam penelitian ini adalah Metode Research and Development (R\&D) Dengan metode ini, akan dihasilkan suatu produk/model baru dengan merujuk model yang sebelumnya.

\section{Matematika}

Design Penelitian: Pemodelan

Terdapat beberapa tahap dalam menyusun model matematika yang dapat dinyatakan dalam alur diagram berikut:

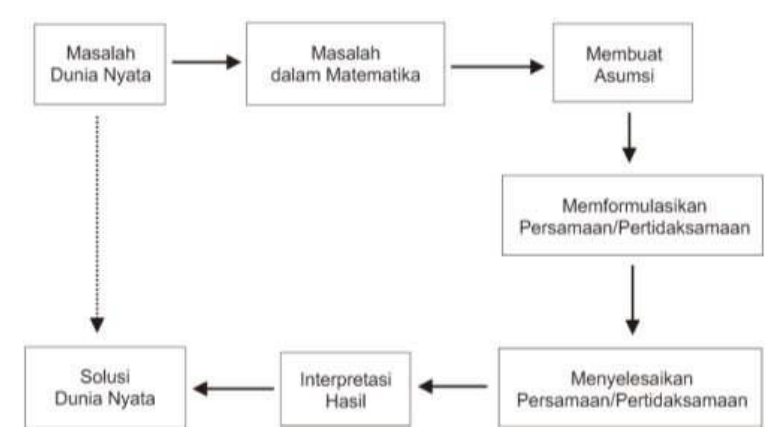

Gambar 1 Langkah-langkah Pemodelan Matematika

Dalam Pemodelan Matematika, hal pertama yang harus dilakukan adalah memodelkan masalah dunia nyata ke dalam matematika. Hal ini sangat penting dilakukan karena dalam tahapan awal pemodelan ada asumsiasumsi yang harus dipenuhi sebelum melakukan pemodelan, yaitu mendefinisikan variabel dan parameter untuk kemudian dimodelkan dan dibuat rumus matematikanya. Dari rumus matematika yang sudah dibuat, akan dilihat bagaimana jumlah rakaat shalat tersebut akan mempengaruhi banyaknya kalori yang dibakar. Keteraturan atau suatu pola rakaat shalat bisa dicari, kemudian dilihat berapa waktu yang diperlukan untuk melakukan 1 gerakan shalat. Kalori yang keluar dari setiap gerakan rakaat shalat yang tumakninah tersebut, bisa dihitung dengan asumsi gerakan shalat sama dengan orang melakukan stretching. Dengan menggunakan alur 
di atas, hubungan antara gerakan shalat yang tumakninah dengan kesehatan akhirnya akan didapat. Beberapa Asumsi dan Data

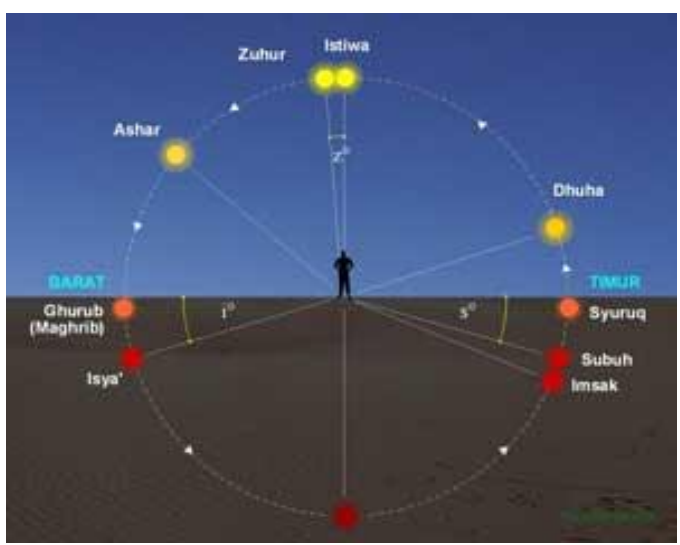

Gambar 2. Pembagian Waktu Shalat Dari gambar di atas dapat dilihat bahwa shalat terbagi menjadi 7 bagian waktu, 5 shalat wajib (subuh, zuhur, ashar, magrib, isya) dan 2 shalat sunnah (dhuha dan tahajud). Dengan jeda waktu antara 1 jam yang paling dekat yaitu shalat Magrib ke Isya, dan 5 jam yaitu dari isya ke tahajud. Dalam pembentukan model matematika ini tidak dilihat jeda waktu antar shalat satu dengan yang lain, tetapi yang dihitung adalah banyaknya rakaat salat yang tumakninah dengan pembakaran kalori dalam tubuh.

\section{Kalori}

Kalori yang masuk setiap hari yang berasal dari asupan makanan. Porsi makanan yang kita santap setiap harinya selalu berbeda, kadang sedikit kadang terlalu banyak. Padahal porsi yang seimbang diperlukan oleh tubuh kita setiap harinya. Jika mengkonsumsi terlalu banyak kalori sedangkan aktivitas kita hanya sedikit, dapat menyebabkan naiknya berat badan bahkan timbulnya penyakit dalam tubuh. Berikut penulis berikan kalori minimal yang masuk dari asupan makanan:

Tabel 1 Banyaknya calori per 1 kali makan

\begin{tabular}{|c|c|c|c|c|}
\hline $\begin{array}{l}\text { Energi } \\
\text { Utama }\end{array}$ & Asupan & Proses Akhir & $\begin{array}{l}\text { Kondisi } \\
\text { Normal }\end{array}$ & 1x makan \\
\hline Karbohidrat & $45-50 \%$ & Monosakarida & $1200 \mathrm{kkal}$ & 400 calori \\
\hline Lemak & $34-40 \%$ & Asam amino & $558 \mathrm{kkal}$ & 100 calori \\
\hline Protein & $\begin{array}{l}10-15 \% \\
\text { Jumlah }\end{array}$ & Asam Lemak & $\begin{array}{r}240 \mathrm{kkal} \\
1998 \mathrm{kkal}\end{array}$ & $\begin{array}{l}100 \text { calori } \\
600 \text { calori }\end{array}$ \\
\hline
\end{tabular}

Dari tabel di atas, banyak calori perhari yang masuk ke dalam tubuh sebesar 1800 calori. Kalori tesebut hanya untuk makanan pokok saja. Dengan kebiasaan ngemil dan jajan akan membuat kadar kalori akan bertambah. Kondisi normal kalori untuk orang dewasa sebanyak 1800 calori sampai 2000 calori. Kelebihan kalori dalam tubuh akan dibakar dengan melakukan gerakan shalat.

Kalori yang keluar saat shalat

Shalat yang dilakukan setiap harinya oleh manusia memiliki gerakan yang bermacam, seperti menggerakkan tangan (takbir), tubuh (ruku' dan sujud), kaki (sujud dan duduk) dan gerakan kepala (salam). Gerakan shalat tersebut penulis asumsikan dengan gerakan stretching (pemanasan sebelum berolah raga), dimana memiliki kesamaan gerakan tangan, tubuh, kaki dan kepala.
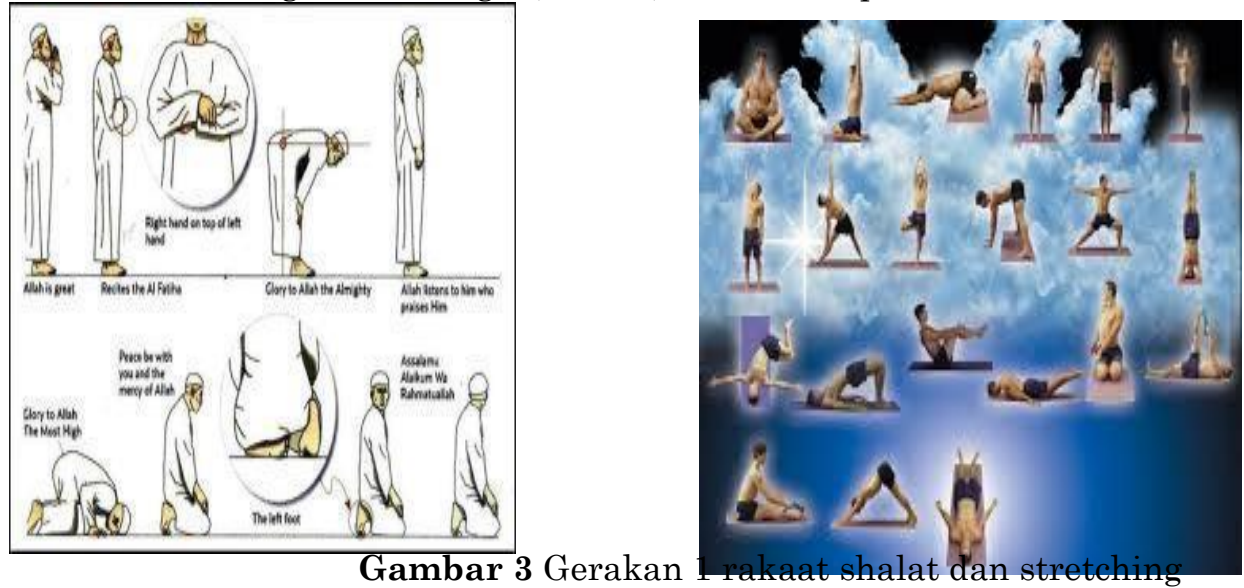

Ketika melakukan stretching, seseorang mengeluarkan kalori sebanyak 100 kalori dalam waktu 10 menit. Asumsi tersebut dijadikan acuan untuk menghitung kalori yang dikeluarkan saat melakukan satu raka'at sholat, yakni sebagai berikut: 
- 100 kalori $=10$ menit

- 10 menit = 1shalat (raka'at)

- 1 shalat $=4$ raka'at dengan tumakninah

- 1 raka'at $=25$ kalori $=2,5$ menit

- Minimal stretching $150 \mathrm{menit} / \mathrm{minggu}=30$ menit perhari

Tabel 2. Lamanya waktu dalam gerakan rakaat shalat yang tumakninah

\begin{tabular}{|c|c|}
\hline \multirow{2}{*}{ Gerakan } & Lama Waktu \\
\cline { 2 - 2 } & (dalam detik) \\
\hline Bacaan & 80 \\
\hline Ruku & 12 \\
\hline I'tidal & 26 \\
\hline Sujud & 24 \\
\hline Duduk & 18 \\
\hline
\end{tabular}

150

\section{HASIL DAN PEMBAHASAN}

$$
\text { Pada langkah ini }
$$

permasalahan jumlah rakaat shalat dan banyaknya kalori yang keluar pada saat shalat yang tumakninah dimodelkan ke dalam bahasa matematika. Langkah ini meliputi pemahaman pada karakteristik permasalahan yang akan dimodelkan kemudian membatasi permasalahan yang akan dibahas. Identifikasi dan pembatasan masalah menghasilkan variabel-variabel yang dapat dibentuk beberapa hubungan antar variable tersebut. Kemudian menjabarkan variabel-variabel dan sistem menjadi model.

Setelah membuat asumsi seperti yang sudah disebutkan pada pembahasan sebelumnya, langkah selanjutnya adalah membuat formulasi persamaan matematika, /pertidaksamaan menyelesaikan persamaan/pertidaksamaan tersebut, kemudian menginterpretasi hasil.

Tabel 3. Shalat, lamanya waktu, dan kalori yang keluar pada saat shalat dengan tumakninah

\begin{tabular}{|c|l|c|c|c|}
\hline No & \multicolumn{1}{|c|}{ Shalat } & $\begin{array}{c}\text { Jumlah } \\
\text { Raka'at }\end{array}$ & $\begin{array}{c}\text { Lamanya waktu } \\
\text { shalat (menit) }\end{array}$ & Kalori yang keluar \\
\hline 1 & Shubuh & 2 & 5 & 50 \\
\hline 2 & Dhuha & 2 & 5 & 50 \\
\hline 3 & Dzuhur & 4 & 10 & 100 \\
\hline 4 & Ashar & 4 & 10 & 100 \\
\hline 5 & Maghrib & 3 & 7,5 & 75 \\
\hline 6 & Isya' & 4 & 10 & 100 \\
\hline 7 & Tahajud & 2 & 5 & 50 \\
\hline \multicolumn{2}{|c|}{ Total } & 52,5 & 525 \\
\hline
\end{tabular}

\section{Formulasi}

Persamaan/Pertidaksamaan

Dengan asumsi dan hubungan antara variabel-variabel, langkah selanjutnya yaitu memformulasikan persamaan atau sistem persamaan. Formulasi model merupakan langkah paling penting, sehingga kadang perlu adanya pengujian kembali asumsi-asumsi agar langkah formulasi persamaan (kumpulan persamaan) yang sesuai sehingga dapat diselesaikan dan relistik. Jika pada proses pengujian kembali, model yang terbentuk tidak sesuai maka perlu dilakukan pengkajian ulang asumsi dan membentuk asumsi yang baru.

Dari asumsi yang ada dipembahasan sebelumnya, didapat kalori yang keluar saat melakukan shalat, yakni sebagai berikut: 
Dengan mendefinisikan $\mathrm{X}$ sebagai rakaat shalat dan $\mathrm{Y}$ sebagai banyaknya kalori yang dikeluarkan pada saat shalat, diperoleh grafik persamaan regresi eksponensial sebagai berikut:

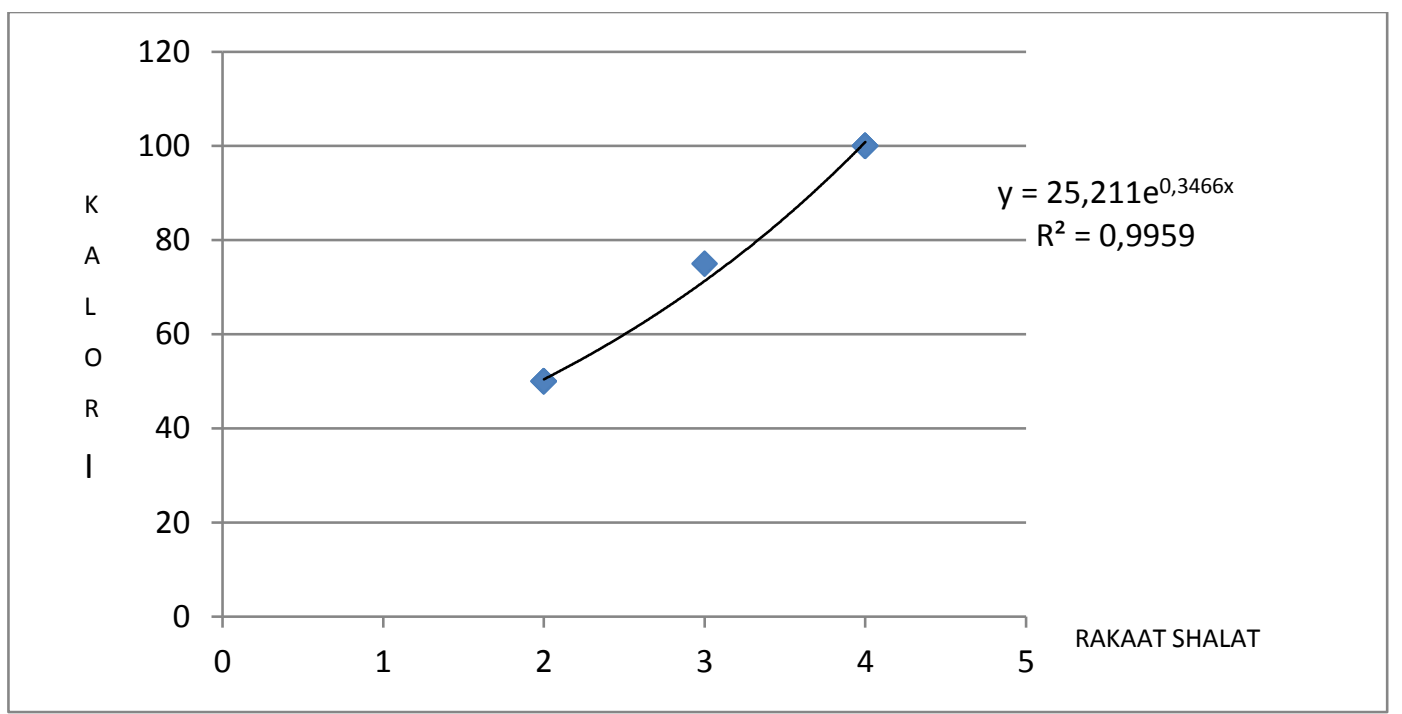

Gambar 4 Grafik Shalat dan banyaknya kalori yang dikeluarkan pada saat shalat tumakninah berikut:

Berdasarkan gambar di atas, diperoleh persamaan regresi eksponensial sebagai

dengan koefisien korelasi

$$
\mathrm{Y}=25,21 \exp (0,346(\mathrm{x}))
$$

$$
\mathrm{R}^{2}=0,995
$$

\section{Menyelesaikan Persamaan/Pertidaksamaan}

Setelah model diformulasikan, langkah selanjutnya yaitu menyelesaikan persamaan tersebut secara matematis. Dari persamaan tersebut, berikut diberikan pendekatan jumlah kalori yang dibuktian dengan perhitungan:

$\mathrm{Y}=25,21 \exp (0,346(\mathrm{x}))$

1) $\mathrm{x}=2$ (artinya shalat 2 rakaat)

$\mathrm{Y}=25,21 \exp (0,346(2))$

$=50,36219$

2) $\mathrm{x}=4$ (artinya shalat 4 rakaat)

$\mathrm{Y}=25,21 \exp (0,346(4))$

$=100,6089$

3) $\mathrm{x}=3$ (artinya shalat 3 rakaat)

$$
\begin{aligned}
\mathrm{Y} & =\quad 25,21 \exp (0,346(3)) \\
& =\quad 71,18205
\end{aligned}
$$

Jadi, dari pembahasan di atas dapat disimpulkan bahwa jumlah kalori total yang dikeluarkan seseorang ketika melakukan shalat ( 5 waktu + dhuha dan tahajud) dalam satu hari adalah:

$50+50+100+100+75+100+50=525$ kalori.

\section{E. KESIMPULAN}

Setelah mengetahui hasil dari pemodelan kalori pada hasil dan pembahasan sebelumnya, yakni (1) shubuh sebesar 50 kalori, (2) dhuha sebesar 50 kalori, (3) dhuhur sebesar 100 kalori, (4) ashar sebesar 100 kalori, (5) maghrib sebesar 75 kalori, (6) isya' sebesar 100 kalori dan (7) tahajud sebesar 50 kalori. Sedangkan kalori minimal yang masuk dari asupan makanan sebesar $1998 \mathrm{kkal}$. Jadi, dapat disimpulkan bahwa seseorang ketika melakukan shalat 5 waktu ditambah shalat dhuha dan tahajud mampu membakar kalori sebanyak 525 kalori. Hal ini bisa membuat tubuh sehat seperti kita melakukan olah raga setiap harinya.

Untuk penelitian selanjutnya perlu dibahas pengaruh dari jeda waktu antara shalat satu dengan shalat yang lain beserta manfaatnya. 


\section{F. REFERENSI}

Daftar Buku

Al-Khuli, Hilmi. (2008) Menyingkap Rahasia Gerakan - gerakan Shalat, Yogyakarta : Diva Press.

Mufti, Arifin.(2004) Matematika Alam Semesta. PT Kiblat Buku Utama Bandung.

Muftie, Arifin. (2004) Matematika Alam Semesta Kodetifikasi Bilangan Prima dalam Al Qur'an, P.T. Kiblat Buku Utama Bandung.

Rajin, M.(2011) Pengaruh Shalat Dhuha Terhadap Penurunan Kadar Glukosa darah, Jurnal Eduhealth, Fakultas Ilmu Kesehatan Unipdu Jombang, Ed. 1

Rajin, M.,(2012) Penurunan kadar glukosa darah pada latihan isometric dan IL-sotonik,. Jurnal EduHealth, Vol 2 Nomor 1, April 2012, ISSN 20873271 hal. 6-14. .

Remaud,

Anthony.

(2013)

Isometric/Isotonic Exercise, in

Encyclopedia of Behavioral Medicine,Springer, 1123-24

Shihab, Quraish. (1992) Membumikan ALQuran, Mizan, Bandung

Sholeh, M. (2010). Terapi shalat tahajud menyembuhkan berbagai penyakit. Jakarta: PT Mizan Publika.

Sukadiyanto. (2010). Stres dan cara menguranginya. Jurnal Ilmiah Pendidikan, 29 (1), 45-61.

Sunusi, D.M., (2013). Indahnya shalat malam : tuntunan qiyamul lail dan shalat tarawih. Makassar: Pustaka as-Sunnah.

Syafii, JM, (2008) Sehat Dan Bugar Dengan Kekuatan Gerakan Shalat.Cikarang: Duha Khasanah.

\section{Daftar Website}

http://definisi_sholat diakses pukul 13.04 tanggal 2 Agustus 2017

http://gambar_gerakan_sholat diakses pukul 22.00 tanggal 9 November 2017

http://keutamaan-sholat-untukkesehatan.com diakses pukul 11.30 tanggal 11 November 2017 http://kalori-saat-stretching//olahraga diakses pukul 21.30 tanggal 9 November 2017

https://muslim.or.id/13845-tumaninahdalam-shalat-1.html diakses pukul 11.12 tanggal 11 November 2017

http://qurandansunnah.wordpress.com/201 0/05/27/kebutuhan-kalori-manusia/ diakses pukul 20.00 tanggal 10 November 2017

http://rukyatulhilal.org/artikel/awalwaktu-shalat-perspektif-syari-dansains.html diakses pukul 21.00 tanggal 10 November 2017

http://wikaprima.wordpress.com/infokesehatan/manfaat-gerakansholat-bagi-kesehatan/ diakses pukul 20.14 tanggal 10 November 2017 